Proc. Estonian Acad. Sci. Geol., 2003, 52, 2, 69-86

\title{
Glauconitic rocks in the Baltic area: estimation of specific surface
}

\author{
Alla Shogenova ${ }^{\mathrm{a}}$, Ida L. Fabricius ${ }^{\mathrm{b}}$, Uffe Korsbech ${ }^{\mathrm{c}}$, Vita Rasteniene ${ }^{\mathrm{d}}$, \\ and Saulius Šliaupa ${ }^{\mathrm{d}}$ \\ a Institute of Geology, Tallinn Technical University, Estonia pst. 7, 10143 Tallinn, Estonia; \\ alla@gi.ee \\ b Environment and Resources, Technical University of Denmark, b. 204, DK-2800 Lyngby, \\ Denmark; ilf@er.dtu.dk \\ c Ørsted-DTU, Technical University of Denmark, b. 327, DK-2800 Lyngby, Denmark \\ ${ }^{d}$ Institute of Geology, T. Ševcenkos 13, LT 2600 Vilnius, Lithuania
}

Received 25 March 2002, in revised form 20 November 2002

\begin{abstract}
We studied 97 samples from the Baltic area, having varying lithology (limestone, dolomite, dolomitic and calcareous marlstones, and siliciclastics), geological age (Cambrian, Ordovician, Cretaceous, Palaeogene, and Neogene), and thermal history (weakly heated Estonian and Russian samples, more heated Lithuanian samples, and most heated Danish and Polish samples). It was found that the specific surface of glauconite-bearing reservoir rocks could be estimated indirectly from the potassium content as measured by gamma spectrometry, and from magnetic susceptibility. The relationship between the potassium content and specific surface is best defined for a given geological age and thermal history, but is largely independent of lithology. The relationship between magnetic susceptibility and specific surface is best defined for specific lithologies and geological age, but is largely unaffected by thermal history. The thorium and uranium contents as measured by gamma spectrometry gave no clear indication of specific surface.
\end{abstract}

Key words: specific surface area, specific magnetic susceptibility, U, Th, K, glauconite-bearing rocks, Baltic area, thermal history.

\section{INTRODUCTION}

Glauconite-bearing reservoir rocks may raise difficulties in the assessment of the reservoir quality from petrophysical data because, firstly, glauconite is characterized by microporosity and, secondly, due to its exchangeable cations, glauconite gives rise to excess conductivity of reservoir brine (Hamada et al. 1999). The first reason causes high irreducible water saturation, the second may cause an overestimation of water saturation during log evaluation unless special precautions are taken.

The excess conductivity of a glauconite-bearing sample can be estimated from the specific surface unless other clay minerals dominate the samples (Nybakk et al. in press). In the present paper we study the possibility of estimating the 
specific surface of glauconite-bearing carbonates and sandstones from natural gamma-ray and magnetic susceptibility data.

Samples were collected from formations of Cambrian, Ordovician, Cretaceous, Palaeogene, and Neogene age over a large area in the Baltic, representing more than $2 \mathrm{~km}$ difference in (palaeo-) burial depth of the Palaeozoic rocks. Lower Palaeozoic black shales contain vitrinite-like macerals from where "vitrinite" reflectance can be measured. In Estonia the reflectance is below 0.55\%, corresponding to immaturity with respect to oil formation; in Lithuania the reflectance is between $0.55 \%$ and $1.40 \%$, corresponding to maturity with respect to oil formation, and on the Danish island of Bornholm the reflectance is near $2.70 \%$, corresponding to post-maturity with respect to oil formation. The NE-SW maturity trend is probably caused by the distance to the Caledonian orogenic front (Buchardt \& Lewan 1990; Buchardt et al. 1997). In this way we can evaluate the possibility of estimating the specific surface as a function of lithology, geologic age, and thermal history.

\section{SAMPLE MATERIAL}

Ninety-seven samples were collected from outcrops or drill cores in five countries: Denmark, Estonia, Lithuania, Poland, and Russia (Fig. 1, Table 1). All 13 Cambrian samples are siliciclastics of Lower Cambrian age. The single

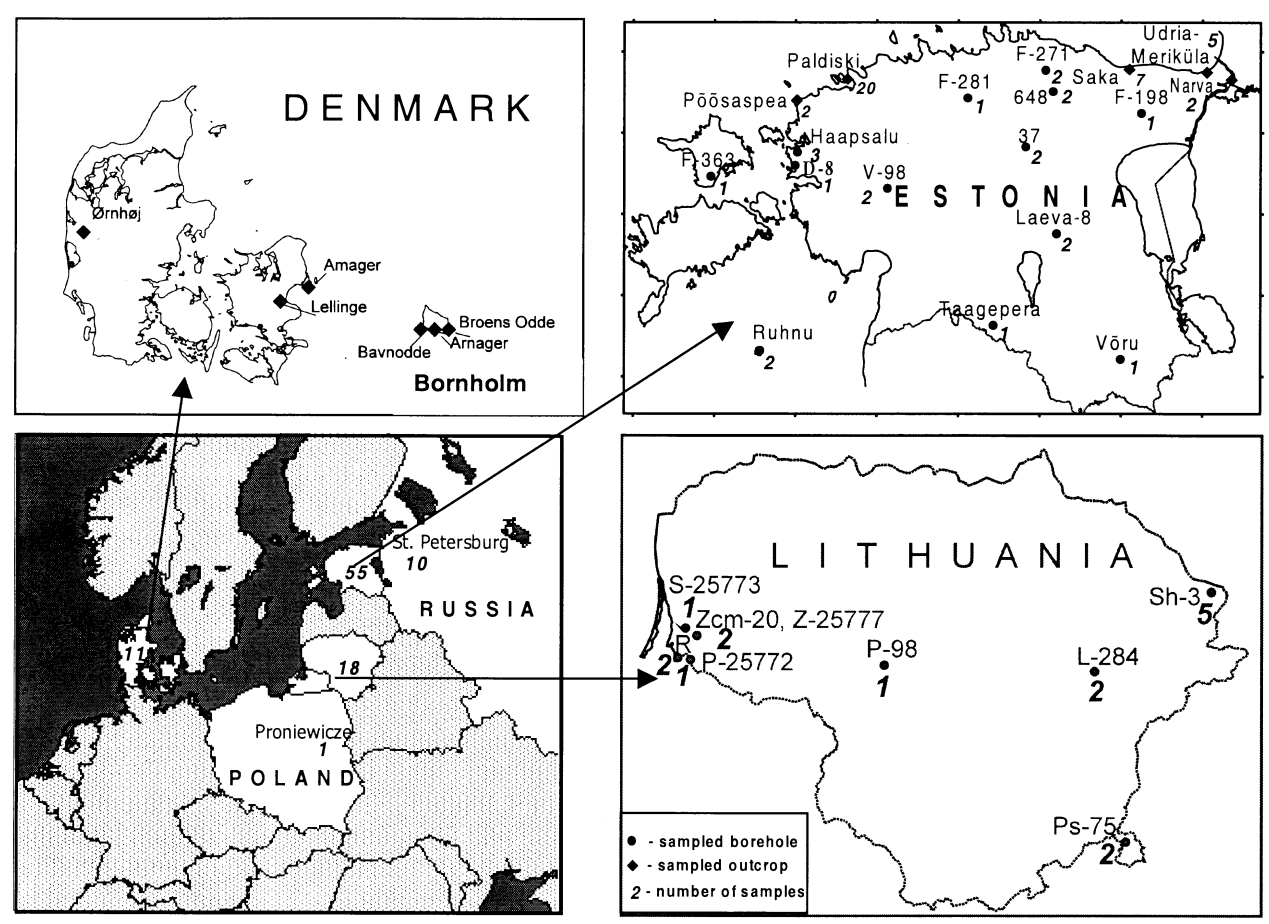

Fig. 1. Location of sample sites. 
Cambrian sample from Estonia is silty clay from shallow burial, whereas the Cambrian samples from Lithuania and Denmark (Hansen 1936) are siltstones and sandstones (Fig. 2a, b). The 69 Ordovician samples are mainly from Estonia and

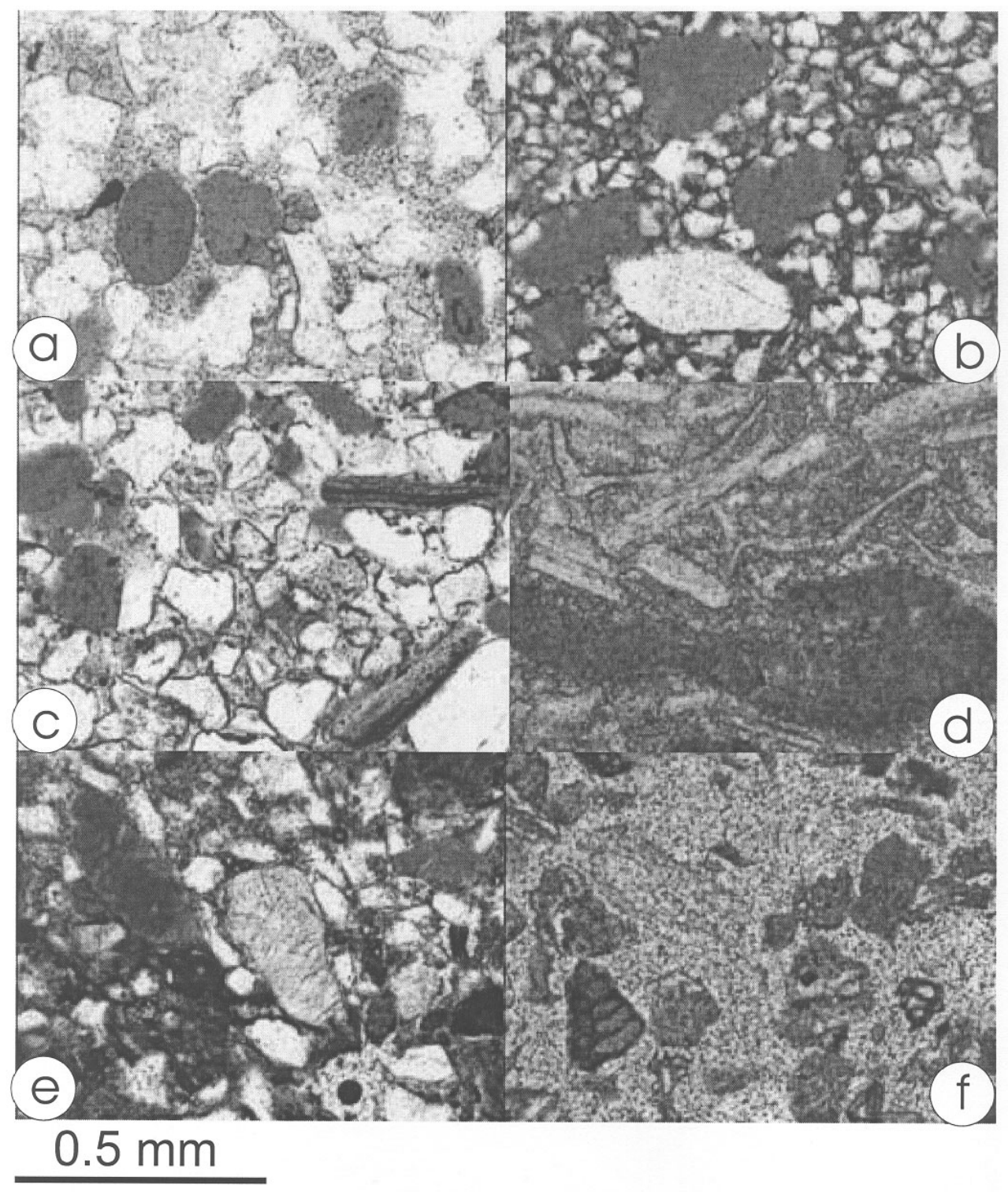

Fig. 2. Thin-section micrographs of (a) Cambrian sandstone with glauconite from borehole Sh-3, Lithuania; (b) Cambrian glauconitic siltstone from Broens Odde, Denmark; (c) Ordovician calcitecemented glauconitic sandstone from Paldiski, Pakri Peninsula klint, Estonia; (d) Ordovician limestone with glauconite from Paldiski, Pakri Peninsula klint, Estonia; (e) Cretaceous glauconitic siltstone from Bavnodde, Bornholm, Denmark; (f) Palaeogene greensand from Arnager, Bornholm, Denmark. 


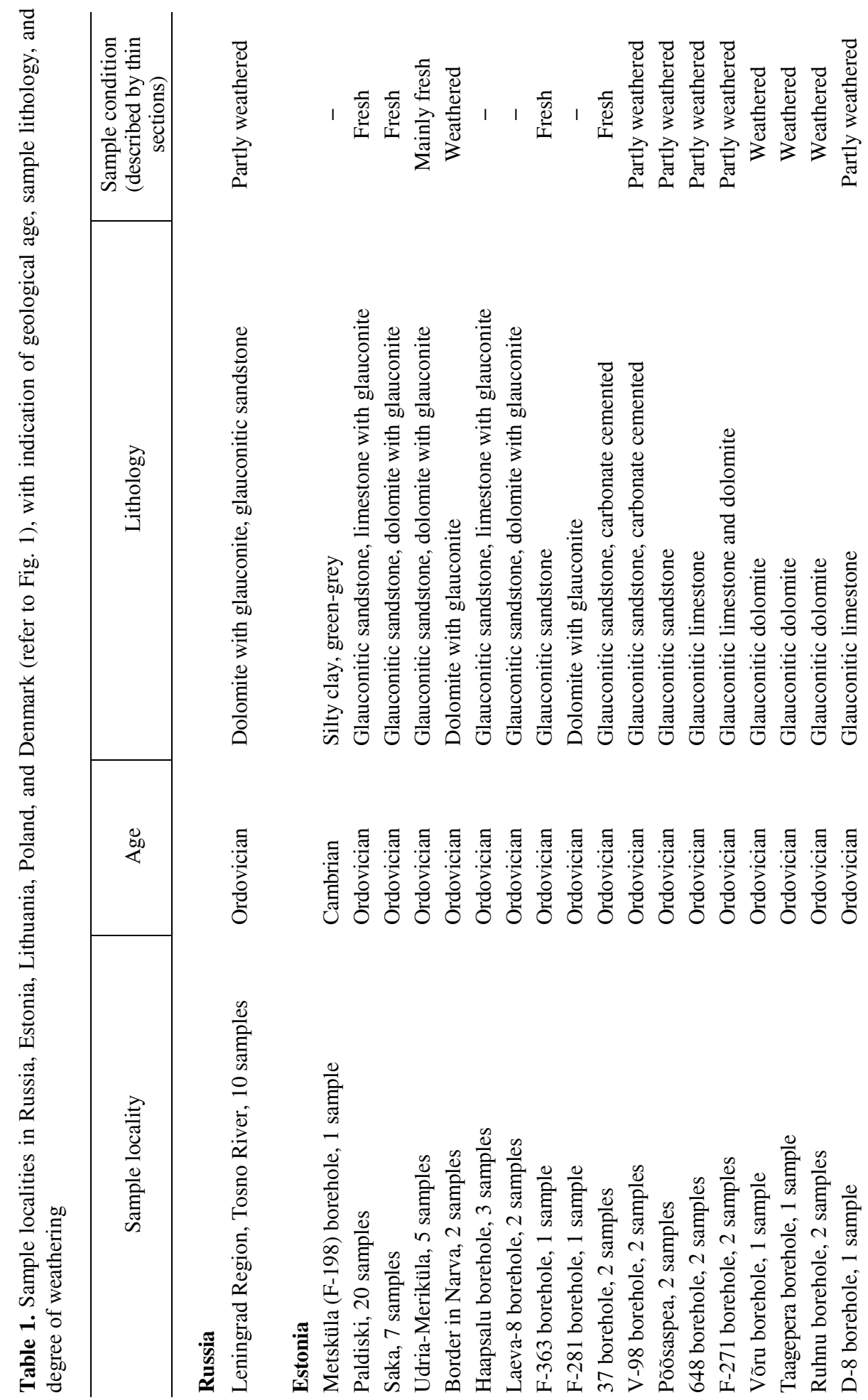




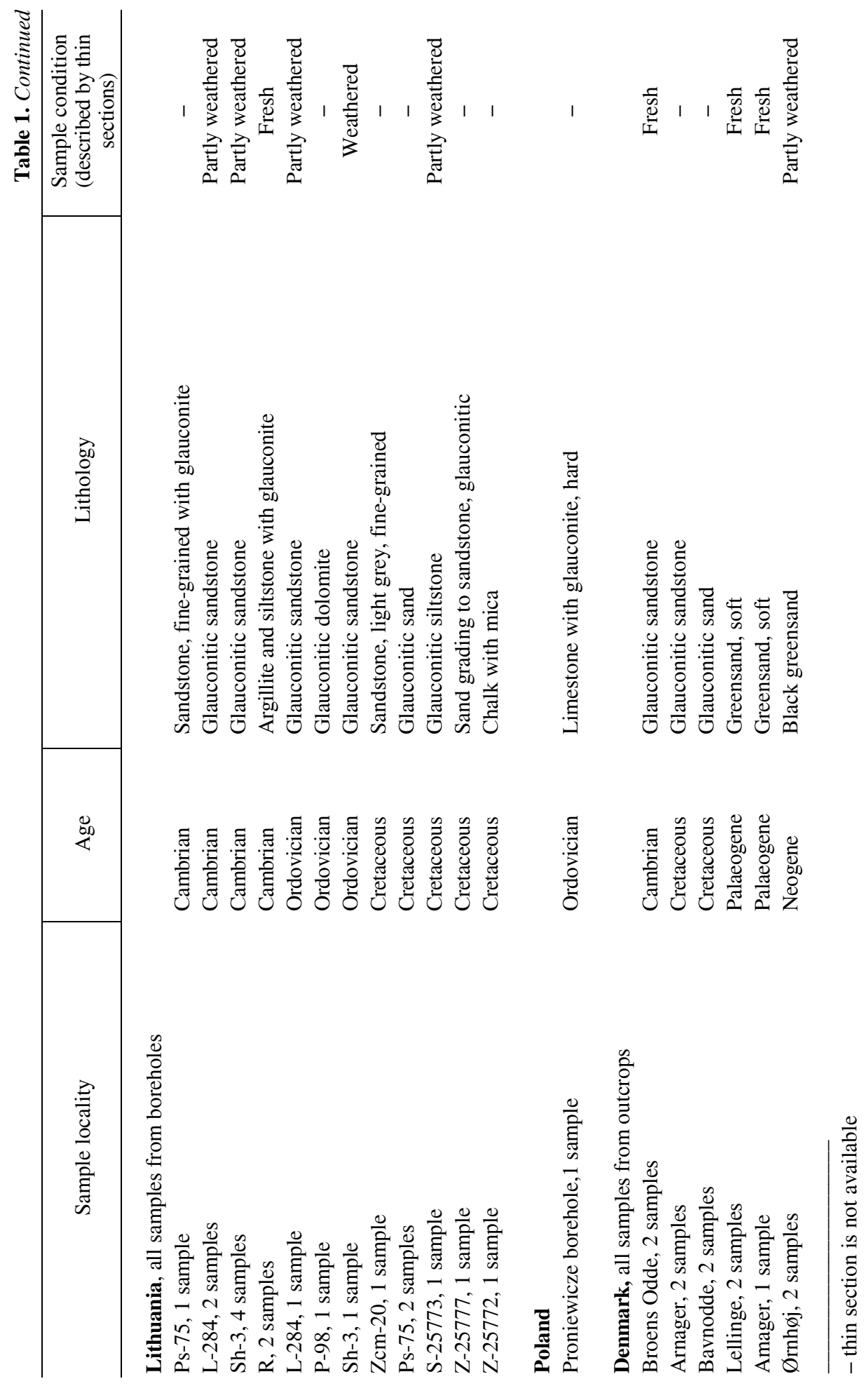


comprise 27 glauconitic sandstones (Fig. 2c) from the Lower Ordovician Hunneberg and Billigen stages, as well as 42 glauconite-bearing carbonates from the Middle Ordovician Volkhov and Kunda stages (Meidla 1997). Ordovician limestone and calcareous marlstone with glauconite were sampled in the northwestern part of Estonia (13 samples, Fig. 2d), Eastern Lithuania (one sample), and Poland (one sample; Modlinski \& Szymanski 1997), whereas dolomite and dolomitic marlstones with glauconite were sampled in eastern and southern Estonia (19 samples), the Leningrad Region near St. Petersburg (seven samples; Popov 1997), and central Lithuania (one sample). Ten glauconitic Cretaceous samples were collected in Lithuania (four siliciclastics, two limestones (chalk); Cyziene \& Šliaupa 1999) and Bornholm, Denmark (four siliciclastics, Fig. 2e; Gry 1960). The Palaeogene is represented by three Palaeocene limestone samples from Arnager, Denmark (Fig. 2f), and the Neogene by two Middle Miocene siliciclastics from Jutland, Denmark.

Seven samples, mainly from boreholes, were judged to be weathered, because of their rusty appearance, 17 samples were judged to be partly weathered. Heporosity of the glauconite-bearing siliciclastic samples is in the range $12-26 \%$, except for the two Cambrian samples from Denmark with porosities of 3-4\%. Limestone samples have He-porosity in the range $1-14 \%$, and dolomite samples in the range $3-11 \%$.

\section{ANALYTICAL METHODS}

Bulk chemical composition $\left(\mathrm{SiO}_{2}, \mathrm{CaO}, \mathrm{MgO}, \mathrm{MnO}, \mathrm{Fe}_{2} \mathrm{O}_{3}\right.$ total, $\mathrm{K}_{2} \mathrm{O}, \mathrm{Na}_{2} \mathrm{O}$, $\mathrm{Al}_{2} \mathrm{O}_{3}, \mathrm{TiO}_{2}, \mathrm{P}_{2} \mathrm{O}_{5}, \mathrm{Ba}, \mathrm{Cr}, \mathrm{V}, \mathrm{S}$ ) was measured by X-ray fluorescence analysis, and divalent iron $(\mathrm{FeO})$ by photocolorimetry at the All-Russian Geological Institute (VSEGEI), St. Petersburg. In addition, wet chemical analysis of carbonates $\left(\mathrm{CaO}, \mathrm{MgO}\right.$, insoluble residue, $\left.\mathrm{CO}_{2}\right)$ was made at Tallinn Technical University (Table 2).

The gamma radiation from $\mathrm{K}$, Th, and $\mathrm{U}$ in 80 powdered rock samples was measured by a NaI crystal gamma spectrometer at Technical University of Denmark (DTU; Table 3). The specific surface area of rocks was measured at DTU by the Brunauer, Emmett, and Teller (BET) method with a Gemini III 2375 surface area analyser (Micromeritics Instruments Corp.) using nitrogen (99.999\% pure) as adsorbate (Table 2). Prior to the measurements, the samples were outgassed at $70{ }^{\circ} \mathrm{C}$ on a FlowPrep 060 Degasser (Micromeritics Instruments Corp.) using nitrogen as a carrier gas. The principle of the BET method is that nitrogen gas adsorbs in a monomolecular layer on a dry solid surface (Brunauer et al. 1938).

The mineral content was determined at DTU from thin-section microscopy and X-ray diffractometry. A Philips diffractometer with $\mathrm{CuK} \alpha$-radiation and graphite monochromator and an automatic divergent slit were used. Thin sections were prepared in the vertical direction where sample orientation is known. Highly 
porous and unconsolidated samples were impregnated with epoxy resin prior to preparation of thin sections. Magnetic susceptibility $(\kappa)$ was measured on both hard samples and powders on Kappabridge KLY-2.01 in the Danish National Museum. The weight of samples $(m)$ was measured, and specific magnetic susceptibility $(k)$ was calculated using the formula $k=\kappa / m$ (Table 3 ).

He-porosimetry is based on the law of Boyle-Mariotte. He-gas has the properties of an ideal gas and is perfect for porosimetry. The method involves a sample chamber and reference chamber, both with a known volume. The dry sample of a known bulk volume is placed in the sample chamber which is set under a vacuum. The reference chamber is filled with He-gas at a known pressure, the gas is expanded from the reference chamber to the sample chamber, the resultant pressure is measured, and the grain volume of the sample (and thus the porosity) can be calculated. The apparatus used is HPG 100 (EPS).

Table 2. Specific surface as measured by BET, total iron content measured by X-ray fluorescence analysis (calculated as $\mathrm{Fe}_{2} \mathrm{O}_{3}$ ), insoluble residue (IR) from treatment with hydrochloric acid, and $\mathrm{Mg} / \mathrm{Ca}$ atomic ratio derived from $\mathrm{X}$-ray fluorescence analysis

\begin{tabular}{|c|c|c|c|c|c|}
\hline Sample locality & Age & $\begin{array}{l}\mathrm{BET}, \mathrm{m}^{2} / \mathrm{g} \\
\mathrm{Avg}(\mathrm{SD})\end{array}$ & $\begin{array}{c}\mathrm{Fe}_{2} \mathrm{O}_{3} \text { total, } \\
\% \\
\text { Avg (SD) }\end{array}$ & $\begin{array}{c}\mathrm{IR}, \% \\
\operatorname{Avg}(\mathrm{SD})\end{array}$ & $\begin{array}{c}\mathrm{Mg} / \mathrm{Ca} \\
\mathrm{Avg}(\mathrm{SD})\end{array}$ \\
\hline \multicolumn{6}{|l|}{ Russia } \\
\hline $\begin{array}{l}\text { Leningrad Region, Tosno } \\
\text { River, } 10 \text { samples }\end{array}$ & Ordovician & $14(8)$ & $5.6(1.3)$ & $40(29)$ & $0.7(0.2)$ \\
\hline \multicolumn{6}{|l|}{ Estonia } \\
\hline $\begin{array}{l}\text { Metsküla (F-198) borehole, } \\
1 \text { sample }\end{array}$ & Cambrian & 0.4 & 3.3 & 78 & 0.63 \\
\hline Paldiski, 20 samples & Ordovician & $11(4)$ & $5.0(1.7)$ & $66(28)$ & $0.4(0.3)$ \\
\hline Saka, 7 samples & Ordovician & $28(13)$ & $8.9(2.3)$ & $65.4(32)$ & $1.8(0.7)$ \\
\hline Udria-Meriküla, 5 samples & Ordovician & $23(13)$ & $8.5(1.9)$ & $52(29)$ & $1.3(0.8)$ \\
\hline Border in Narva, 2 samples & Ordovician & $4.6(0.3)$ & $5.0(1.6)$ & $11(2.2)$ & $0.78(0.02)$ \\
\hline $\begin{array}{l}\text { Haapsalu borehole, } \\
3 \text { samples }\end{array}$ & Ordovician & $19(13)$ & $7(4)$ & $43(36)$ & $1.1(1.6)$ \\
\hline Laeva- 8 borehole, 2 samples & Ordovician & $19(5)$ & $8(9)$ & $56(22)$ & $0.63(0.09)$ \\
\hline F-363 borehole, 1 sample & Ordovician & 33 & 16 & 79.3 & 2.39 \\
\hline F-281 borehole, 1 sample & Ordovician & 14.1 & 10.3 & 40.2 & 0.73 \\
\hline 37 borehole, 2 samples & Ordovician & $7.9(5.6)$ & $4.2(1.7)$ & $30(25)$ & $0.63(0.09)$ \\
\hline V-98 borehole, 2 samples & Ordovician & $2.67(0.03)$ & $3.0(0.6)$ & $9(3)$ & $0.69(0.17)$ \\
\hline Põõsaspea, 2 samples & Ordovician & $0.51(0.01)$ & 1.4 & 72 & 0.27 \\
\hline
\end{tabular}


Table 2. Continued

\begin{tabular}{|c|c|c|c|c|c|}
\hline Sample locality & Age & $\begin{array}{l}\mathrm{BET}, \mathrm{m}^{2} / \mathrm{g} \\
\mathrm{Avg}(\mathrm{SD})\end{array}$ & $\begin{array}{c}\mathrm{Fe}_{2} \mathrm{O}_{3} \text { total, } \\
\% \\
\text { Avg (SD) }\end{array}$ & $\begin{array}{c}\mathrm{IR}, \% \\
\text { Avg }(\mathrm{SD})\end{array}$ & $\begin{array}{c}\mathrm{Mg} / \mathrm{Ca} \\
\operatorname{Avg}(\mathrm{SD})\end{array}$ \\
\hline 648 borehole, 2 samples & Ordovician & $5(3)$ & $4.3(0.9)$ & $5.70(0.11)$ & $0.81(0.00)$ \\
\hline F-271 borehole, 2 samples & Ordovician & $3.5(1.9)$ & $7.5(0.4)$ & $8.3(2)$ & $0.66(0.07)$ \\
\hline Võru borehole, 1 samples & Ordovician & 7.8 & 9.5 & 25.4 & 0.80 \\
\hline $\begin{array}{l}\text { Taagepera borehole, } \\
1 \text { sample }\end{array}$ & Ordovician & 15.8 & 12 & 41.8 & 0.85 \\
\hline Ruhnu borehole, 2 samples & Ordovician & $12(14)$ & 19.9 & 57.8 & 0.93 \\
\hline D- 8 borehole, 1 samples & Ordovician & 4.2 & 1.64 & 7.9 & 0.03 \\
\hline \multicolumn{6}{|c|}{ Lithuania, all samples from boreholes } \\
\hline Ps-75, 1 sample & Cambrian & 2.1 & 5.1 & 74.2 & 0.38 \\
\hline L-284, 2 samples & Cambrian & $1.7(0.5)$ & $3(3)$ & $85(11)$ & $0.8(0.5)$ \\
\hline Sh-3, 4 samples & Cambrian & $5(3)$ & $3(2)$ & $75(24)$ & $0.69(0.10)$ \\
\hline $\mathrm{R}, 2$ samples & Cambrian & $7(3)$ & $5.0(1.3)$ & $86(52)$ & $2.3(1.3)$ \\
\hline L-284, 1 sample & Ordovician & 18.8 & 6.7 & 73.3 & 0.65 \\
\hline P-98, 1 sample & Ordovician & 8.1 & 4.2 & 21.7 & 0.91 \\
\hline Sh-3, 1 sample & Ordovician & 9.5 & 7.2 & 45 & 0.22 \\
\hline Zcm-20, 1 sample & Cretaceous & 22.8 & 5.3 & 71 & 0.14 \\
\hline Ps-75, 2 samples & Cretaceous & $13(3)$ & $5.2(0.9)$ & $88.3(1.1)$ & $1.64(0.03)$ \\
\hline S-25773, 1 sample & Cretaceous & 45 & 17.6 & 75.5 & 5.1 \\
\hline Z-25777, 1 sample & Cretaceous & 6.9 & 4.1 & 86.4 & 0.39 \\
\hline Z-25772, 1 sample & Cretaceous & 36.2 & 1.8 & 51.6 & 0.03 \\
\hline \multicolumn{6}{|l|}{ Poland } \\
\hline $\begin{array}{l}\text { Proniewicze borehole, } \\
1 \text { sample }\end{array}$ & Ordovician & 5.6 & 3.0 & 10.9 & 0.03 \\
\hline \multicolumn{6}{|c|}{ Denmark, all samples from outcrops } \\
\hline Broens Odde, 2 samples & Cambrian & $6.3(0.5)$ & $6.61(0.11)$ & $86.1(0.1)$ & $1.45(0.15)$ \\
\hline Arnager, 2 samples & Cretaceous & $18.2(0.4)$ & $4.45(0.11)$ & $83(6)$ & $0.4(0.2)$ \\
\hline Bavnodde, 2 samples & Cretaceous & $21.7(1.8)$ & $5.5(0.9)$ & $87(4)$ & $0.8(0.8)$ \\
\hline Lellinge, 2 samples & Palaeogene & $7(4)$ & $1.8(0.5)$ & $6(4)$ & $0.03(0.01)$ \\
\hline Amager, 1 sample & Palaeogene & 5.4 & 2.2 & 6.5 & 0.04 \\
\hline Ørnhøj, 2 samples & Neogene & $37(41)$ & $18.0(1.8)$ & $63(4)$ & $21(15)$ \\
\hline
\end{tabular}

Avg, average; SD, standard deviation 
Table 3. Specific magnetic susceptibility of samples and concentration of the radiogenic elements $\mathrm{U}$, Th, and $\mathrm{K}$ as measured from spectral gamma-ray analysis

\begin{tabular}{|c|c|c|c|c|c|c|}
\hline Sample locality & Age & $\begin{array}{c}\text { Specific } \\
\text { magnetic } \\
\text { susceptibility, } \\
10^{-3} \mathrm{~A} / \mathrm{m} \\
\text { Avg (SD) }\end{array}$ & $\begin{array}{c}\mathrm{U}, \mathrm{ppm} \\
\text { Avg (SD) }\end{array}$ & $\begin{array}{l}\text { Th, ppm } \\
\text { Avg (SD) }\end{array}$ & $\begin{array}{c}\mathrm{K}, \% \\
\text { Avg (SD) }\end{array}$ & $\begin{array}{l}\text { K/Th, } 10^{3} \\
\text { Avg (SD) }\end{array}$ \\
\hline Russia & & & & & & \\
\hline $\begin{array}{l}\text { Leningrad Region, Tosno } \\
\text { River, } 10 \text { samples }\end{array}$ & Ordovician & $10(3)$ & $7(8)$ & $7(4)$ & $1.9(1.1)$ & $1.9(1.4)$ \\
\hline Estonia & & & & & & \\
\hline $\begin{array}{l}\text { Metsküla (F-198) } \\
\text { borehole, } 1 \text { sample }\end{array}$ & Cambrian & 11 & - & - & - & - \\
\hline Paldiski, 20 samples & Ordovician & $8(4)$ & $11(4)$ & $10(5)$ & $1.9(0.8)$ & $3(5)$ \\
\hline Saka, 7 samples & Ordovician & $17(4)$ & $10(6)$ & $12(6)$ & $3.9(1.9)$ & $4(2)$ \\
\hline $\begin{array}{l}\text { Udria-Meriküla, } \\
5 \text { samples }\end{array}$ & Ordovician & $16(4)$ & $8(6)$ & $9(7)$ & $3.3(1.7)$ & $5(4)$ \\
\hline $\begin{array}{l}\text { Border in Narva, } \\
2 \text { samples }\end{array}$ & Ordovician & $6.1(0.5)$ & $3(3)$ & $2.5(0.7)$ & $1.0(0.2)$ & $4.3(1.9)$ \\
\hline $\begin{array}{l}\text { Haapsalu borehole, } \\
3 \text { samples }\end{array}$ & Ordovician & $13(7)$ & $5(2)$ & $10(7)$ & $3(3)$ & $2.4(1.3)$ \\
\hline $\begin{array}{l}\text { Laeva- } 8 \text { borehole, } \\
2 \text { samples }\end{array}$ & Ordovician & $14.0(1.9)$ & 13.1 & 14.2 & 3.5 & 2.4 \\
\hline F-363 borehole, 1 sample & Ordovician & 36 & 2.2 & 4.0 & 5 & 11.9 \\
\hline F-281 borehole, 1 sample & Ordovician & 14 & 7.7 & 10.5 & 2.3 & 2.2 \\
\hline 37 borehole, 2 samples & Ordovician & $7.0(1.6)$ & - & - & - & - \\
\hline V-98 borehole, 2 samples & Ordovician & $5.1(1.4)$ & & & & \\
\hline Põõsaspea, 2 samples & Ordovician & $0.45(0.09)$ & 5.9 & 3.6 & 0.2 & 0.6 \\
\hline 648 borehole, 2 samples & Ordovician & $5.3(1.1)$ & - & - & - & - \\
\hline F-271 borehole, 2 samples & Ordovician & $15.3(0.4)$ & - & - & - & - \\
\hline Võru borehole, 1 sample & Ordovician & 14.9 & - & - & - & - \\
\hline $\begin{array}{l}\text { Taagepera borehole, } \\
1 \text { sample }\end{array}$ & Ordovician & 20.4 & - & - & - & - \\
\hline $\begin{array}{l}\text { Ruhnu borehole, } \\
2 \text { samples }\end{array}$ & Ordovician & $17(20)$ & - & - & - & - \\
\hline D- 8 borehole, 1 sample & Ordovician & 4.1 & 5.6 & 14.8 & 0.7 & 0.5 \\
\hline \multicolumn{7}{|l|}{ Lithuania } \\
\hline Ps-75, 1 sample & Cambrian & 9.6 & 2.4 & 7.5 & 5.1 & 6.8 \\
\hline L-284, 2 samples & Cambrian & $4(5)$ & $\begin{array}{c}0.55 \\
(0.07)\end{array}$ & $3.2(1.6)$ & $\begin{array}{c}0.74 \\
(0.06)\end{array}$ & $2.7(1.2)$ \\
\hline Sh-3, 4 samples & Cambrian & $3.5(1.9)$ & $1.5(0.9)$ & $9(4)$ & $2.0(0.7)$ & $7(3)$ \\
\hline
\end{tabular}


Table 3. Continued

\begin{tabular}{|c|c|c|c|c|c|c|}
\hline Sample locality & Age & $\begin{array}{c}\text { Specific } \\
\text { magnetic } \\
\text { susceptibility, } \\
10^{-3} \mathrm{~A} / \mathrm{m} \\
\text { Avg (SD) }\end{array}$ & $\begin{array}{c}\text { U, ppm } \\
\text { Avg (SD) }\end{array}$ & $\begin{array}{l}\text { Th, ppm } \\
\text { Avg (SD) }\end{array}$ & $\begin{array}{c}\mathrm{K}, \% \\
\text { Avg (SD) }\end{array}$ & $\begin{array}{l}\text { K/Th, } 10^{3} \\
\text { Avg (SD) }\end{array}$ \\
\hline $\mathrm{R}, 2$ samples & Cambrian & $9(2)$ & $6(6)$ & $5(4)$ & $1.6(0.2)$ & $5(4)$ \\
\hline L-284, 1 sample & Ordovician & 13.2 & 7.8 & 1.6 & 3.2 & 3.9 \\
\hline P-98, 1 sample & Ordovician & 7.7 & 3.6 & 3.9 & 1.2 & 3.1 \\
\hline Sh-3, 1 sample & Ordovician & 8.2 & 6.8 & 33.8 & 1.4 & 0.42 \\
\hline Zcm-20, 1 sample & Cretaceous & 7.5 & 3.9 & 1.9 & 1.7 & 9 \\
\hline Ps-75, 2 samples & Cretaceous & $11(4)$ & $2.8(1.3)$ & $2.6(1.4)$ & $2.2(0.1)$ & $10(6)$ \\
\hline S-25773, 1 sample & Cretaceous & 32.4 & 3.5 & 1.6 & 3.5 & 21.9 \\
\hline Z-25777, 1 sample & Cretaceous & 7.6 & 2.0 & 1.9 & 1.3 & 7 \\
\hline Z-25772, 1 sample & Cretaceous & 2.1 & 1.8 & 3.0 & 0.7 & 2.2 \\
\hline \multicolumn{7}{|l|}{ Poland } \\
\hline $\begin{array}{l}\text { Proniewicze borehole, } \\
1 \text { sample }\end{array}$ & Ordovician & 3.6 & 2.6 & 14.3 & 0.75 & 0.5 \\
\hline \multicolumn{7}{|l|}{ Denmark } \\
\hline Broens Odde, 2 samples & Cambrian & $11.10(0.15)$ & $7(6)$ & $7(5)$ & $2.6(0.1)$ & $6(5)$ \\
\hline Arnager, 2 samples & Cretaceous & $6.85(0.05)$ & $3.8(0.7)$ & $3.1(1.6)$ & $\begin{array}{c}1.96 \\
(0.11)\end{array}$ & $7(3)$ \\
\hline Bavnodde, 2 samples & Cretaceous & $8.3(1.4)$ & $4(3)$ & $3.8(1.8)$ & $\begin{array}{c}1.73 \\
(0.09)\end{array}$ & $5(2)$ \\
\hline Lellinge, 2 samples & Palaeogene & $2.0(0.9)$ & $1.7(0.2)$ & $1.5(1.6)$ & $0.3(0.2)$ & $4(3)$ \\
\hline Amager, 1 sample & Palaeogene & 2.0 & 1.8 & 3.1 & 0.35 & 1.1 \\
\hline Ørnhøj, 2 samples & Neogene & $32(4)$ & $12(2)$ & $7(5)$ & $2.8(1.0)$ & $7(7)$ \\
\hline
\end{tabular}

- not measured; Avg, average; SD, standard deviation

\section{CHEMICAL COMPOSITION OF SAMPLES}

On the basis of chemical analysis the samples were divided into five groups (Fig. 3): (1) siliciclastics (50 samples) with less than 5\% $\mathrm{MgO}$ and less than $10 \%$ $\mathrm{CaO}$, (2) limestones (11 samples) with less than $10 \% \mathrm{MgO}$, over $30 \% \mathrm{CaO}$, and less than $25 \%$ insoluble residue, (3) dolomites (15 samples) with over $10 \% \mathrm{MgO}$ and less than $25 \%$ insoluble residue, (4) dolomitic marlstones (12 samples) with over $10 \% \mathrm{CaO}, 25-55 \%$ insoluble residue, and over $5 \% \mathrm{MgO}$, and (5) calcareous marlstones with over $10 \% \mathrm{CaO}$, less than $5 \% \mathrm{MgO}$ and $25-55 \%$ IR (9 samples). The fourth and fifth groups include marlstones and carbonate cemented siliciclastics. From the $\mathrm{SiO}_{2}$ vs. $\mathrm{Al}_{2} \mathrm{O}_{3}$ plot we infer that siliciclastics are mixtures of quartz and clay, most dolomites and limestones are mixtures of carbonate and clay, whereas marlstones are mixtures of quartz, clay, and carbonate (Fig. 3c). 
(a)
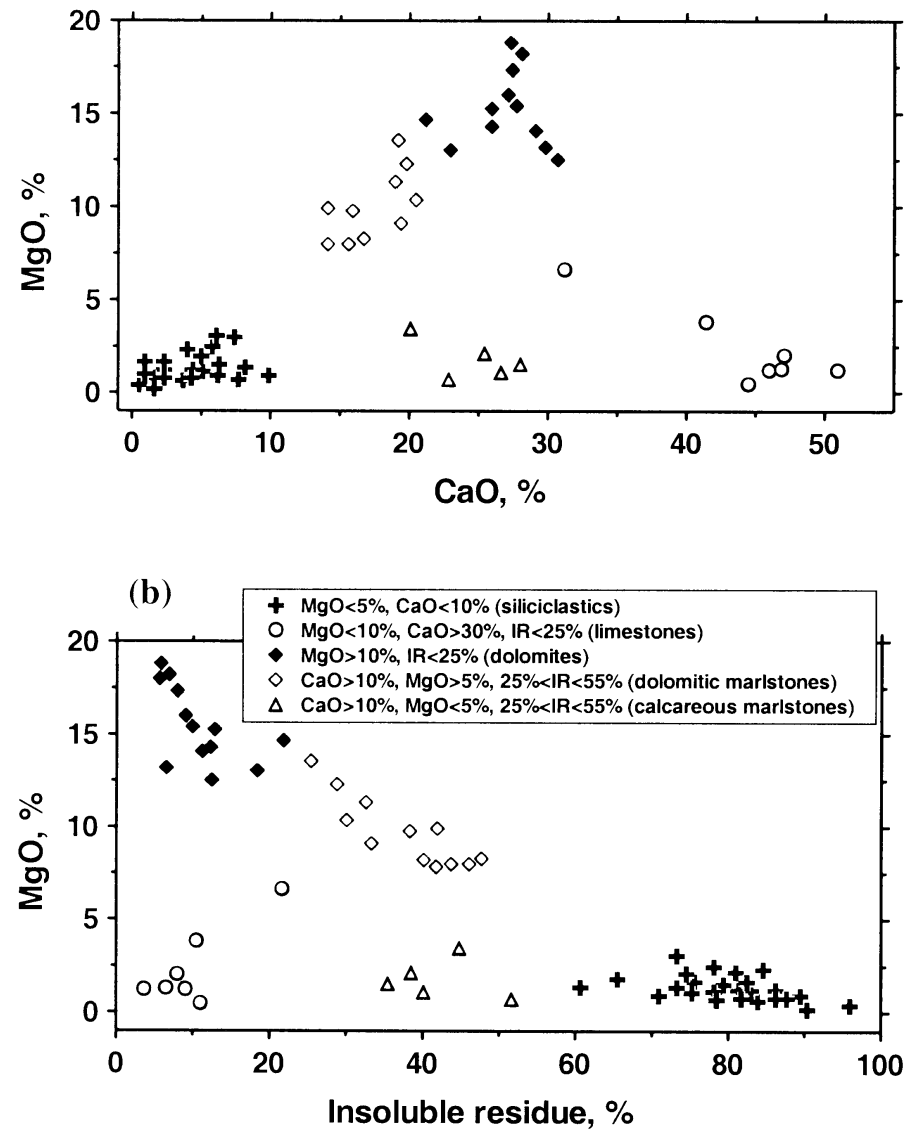

(c)

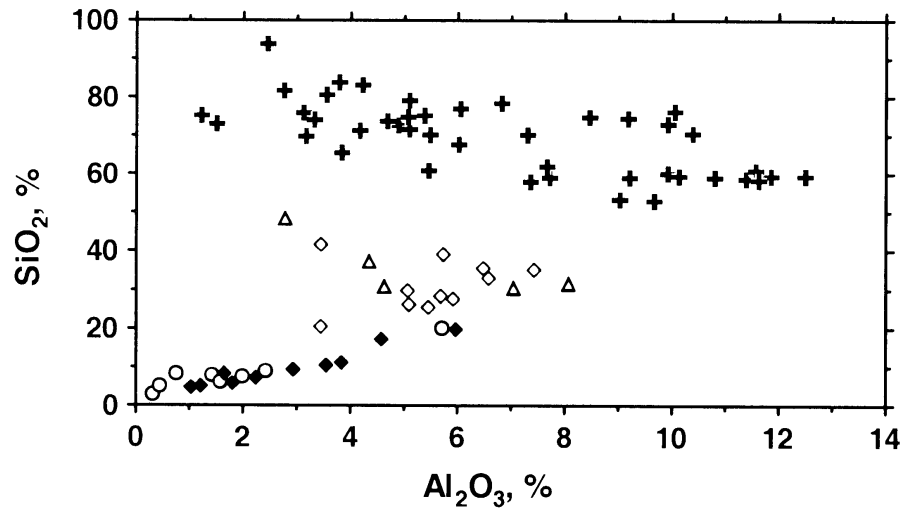

Fig. 3. (a) $\mathrm{MgO}$ content versus $\mathrm{CaO}$ content for five groups of samples; (b) $\mathrm{MgO}$ content versus insoluble residue content; (c) $\mathrm{SiO}_{2}$ content versus $\mathrm{Al}_{2} \mathrm{O}_{3}$ content: the positive relationship for carbonates (limestones and dolomites) and the negative relationship for siliciclastics indicate admixture of clay, whereas marlstones may contain clay and silica. 
Studies of glauconite by Mössbauer spectrometry (DeVoe \& Spijkerman 1966) show that practically all iron in glauconite is in ferric form $\left(\mathrm{Fe}_{2} \mathrm{O}_{3}\right)$. The glauconites from Arnager and Ørnhøj both contain 20\% $\mathrm{Fe}_{2} \mathrm{O}_{3}$ (Nybakk 2002).

The severity of weathering of the samples was expected to influence the relationship between $\mathrm{FeO}$ (ferrous iron) and $\mathrm{Fe}_{2} \mathrm{O}_{3}$ (ferric iron) because oxidation leads to an increase in $\mathrm{Fe}_{2} \mathrm{O}_{3}$ (Fig. 4a). The ratio of magnetic susceptibility to total iron $\left(\mathrm{Fe}_{2} \mathrm{O}_{3}\right.$ total $)$ is apparently not affected by the weathering (Fig. $\left.4 \mathrm{~b}\right)$. This indicates that the magnetic susceptibility is a good measure of total iron content irrespective of weathering and thus we decided to include the weathered and partly weathered samples in the study.

(a)

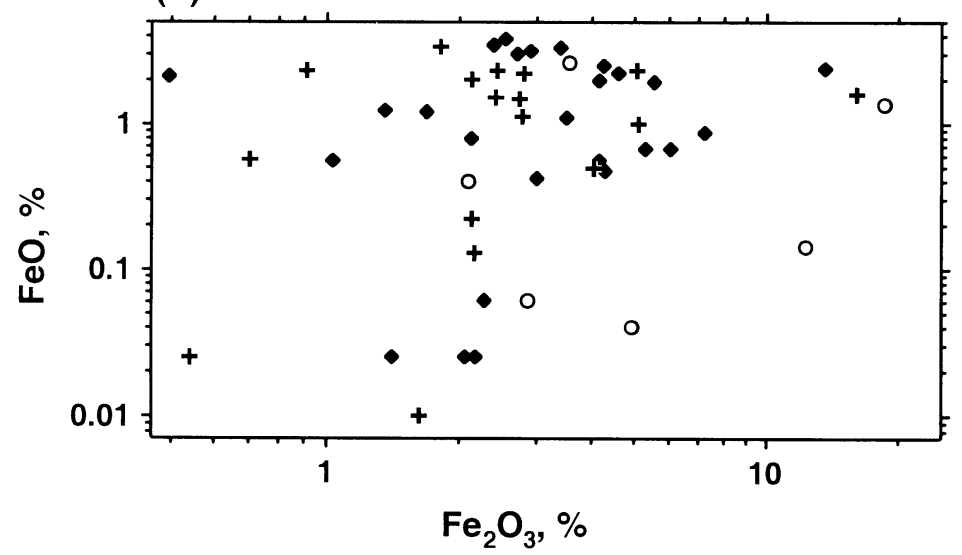

(b)

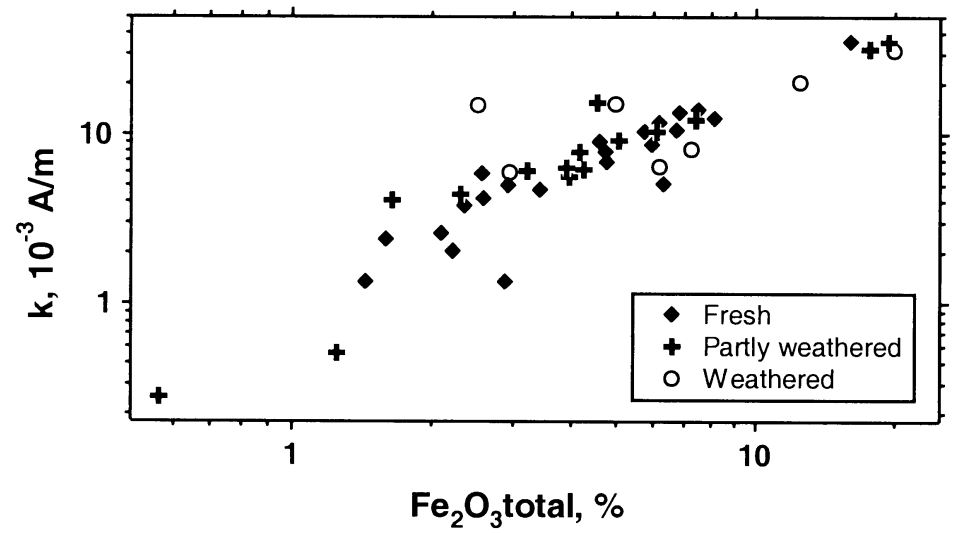

Fig. 4. (a) $\mathrm{FeO}$ versus $\mathrm{Fe}_{2} \mathrm{O}_{3}$ : weathered samples tend to be rich in $\mathrm{Fe}_{2} \mathrm{O}_{3}$, whereas partly weathered samples fall in the same range as fresh samples; (b) specific magnetic susceptibility, $k$ (in logdecimal scale), versus total iron content. All samples, irrespective of weathering, show a distinct relationship between specific magnetic susceptibility, $k$, and total iron content. 

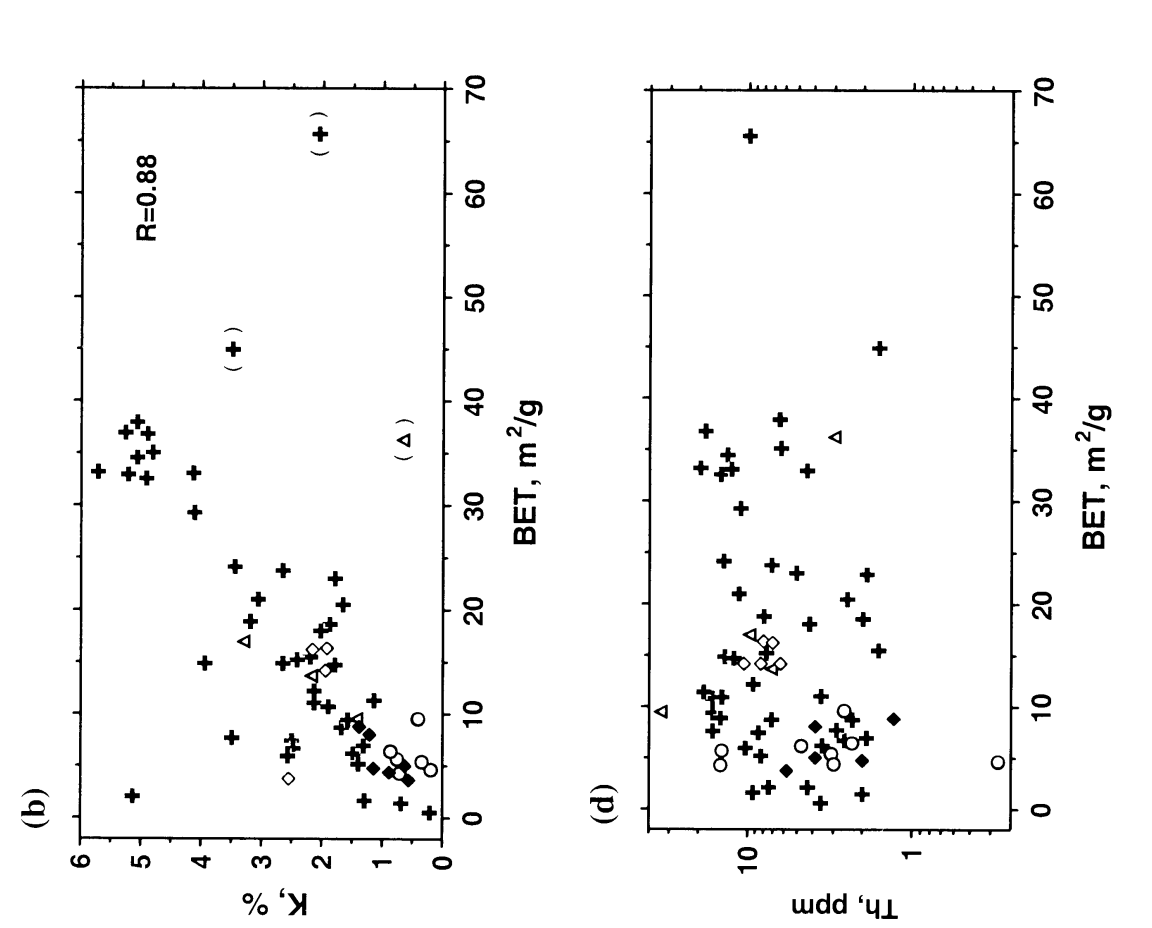

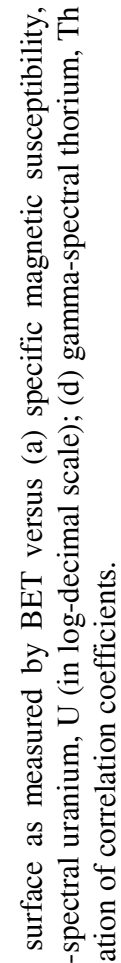
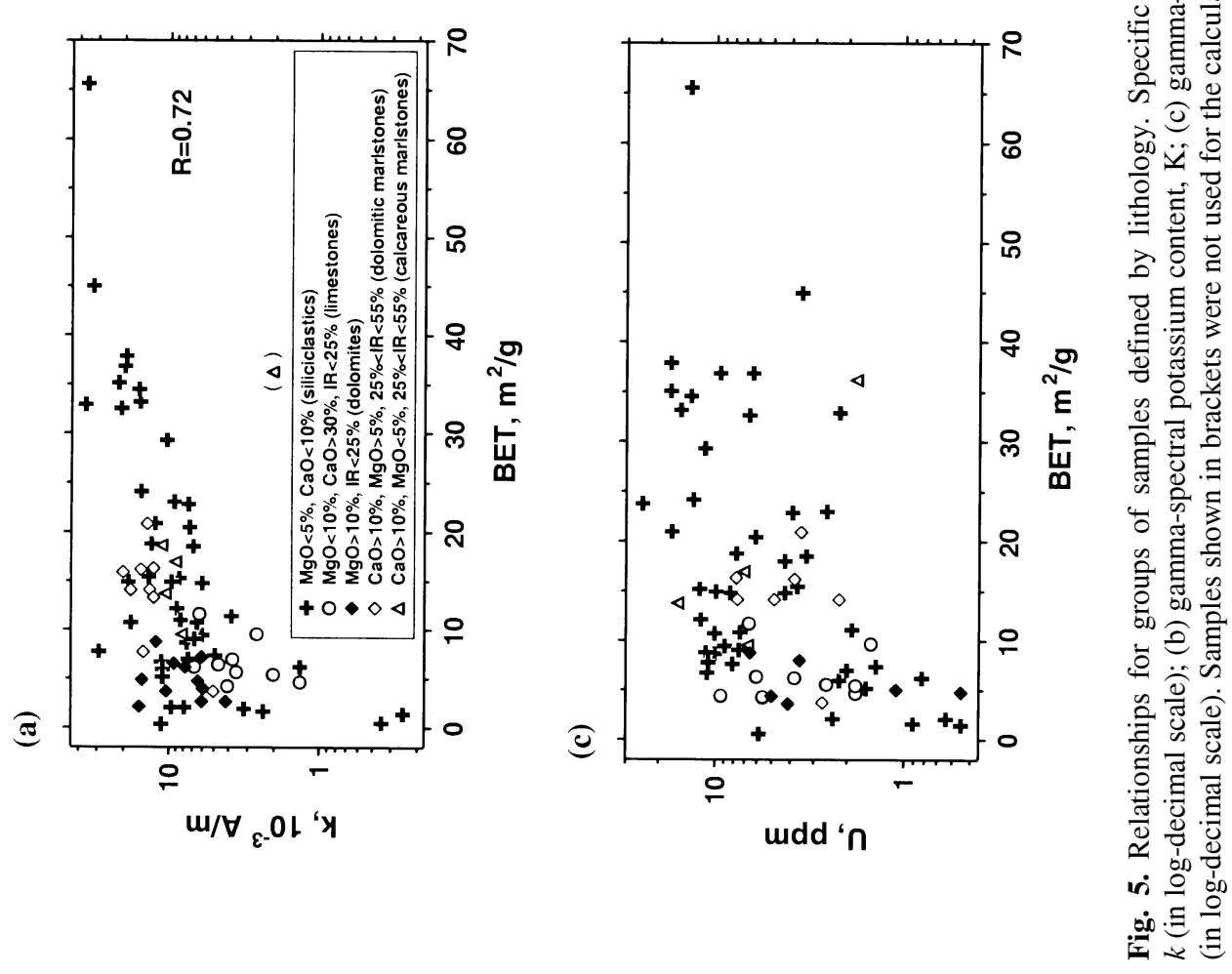

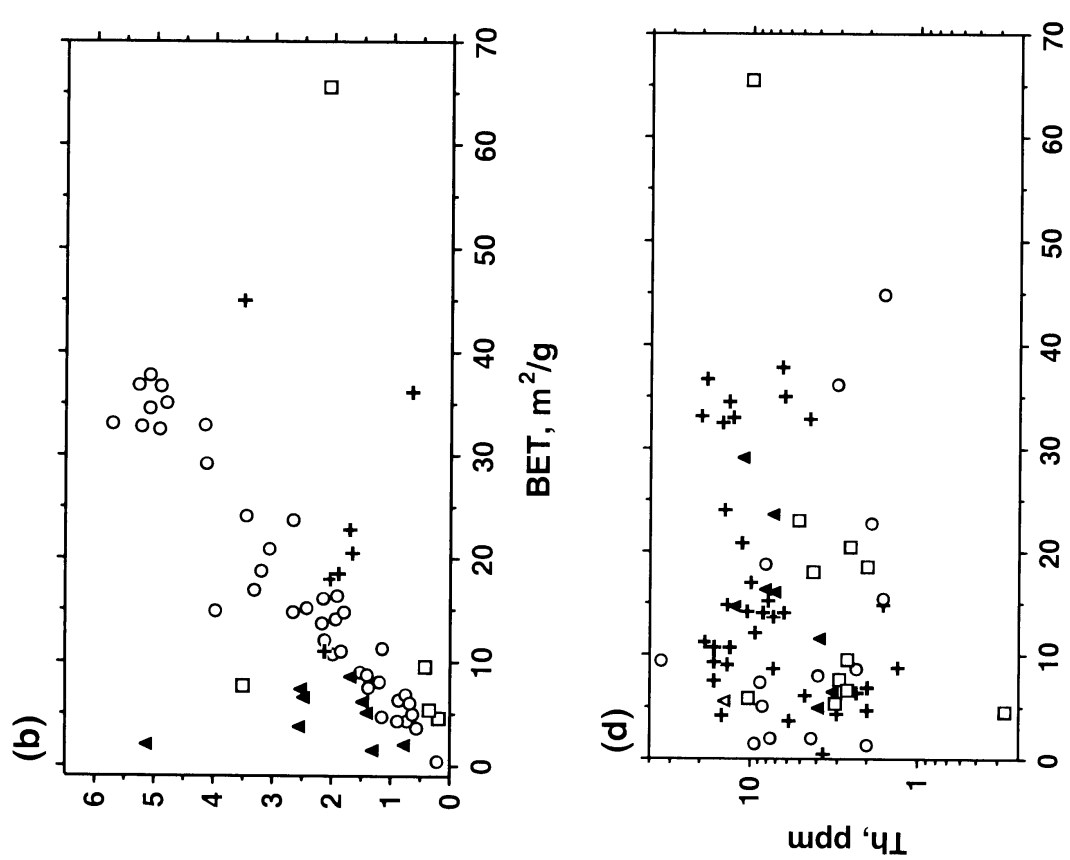

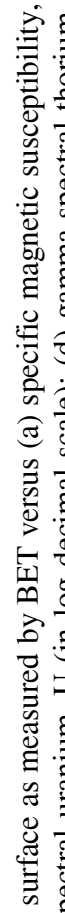

\% 'XX
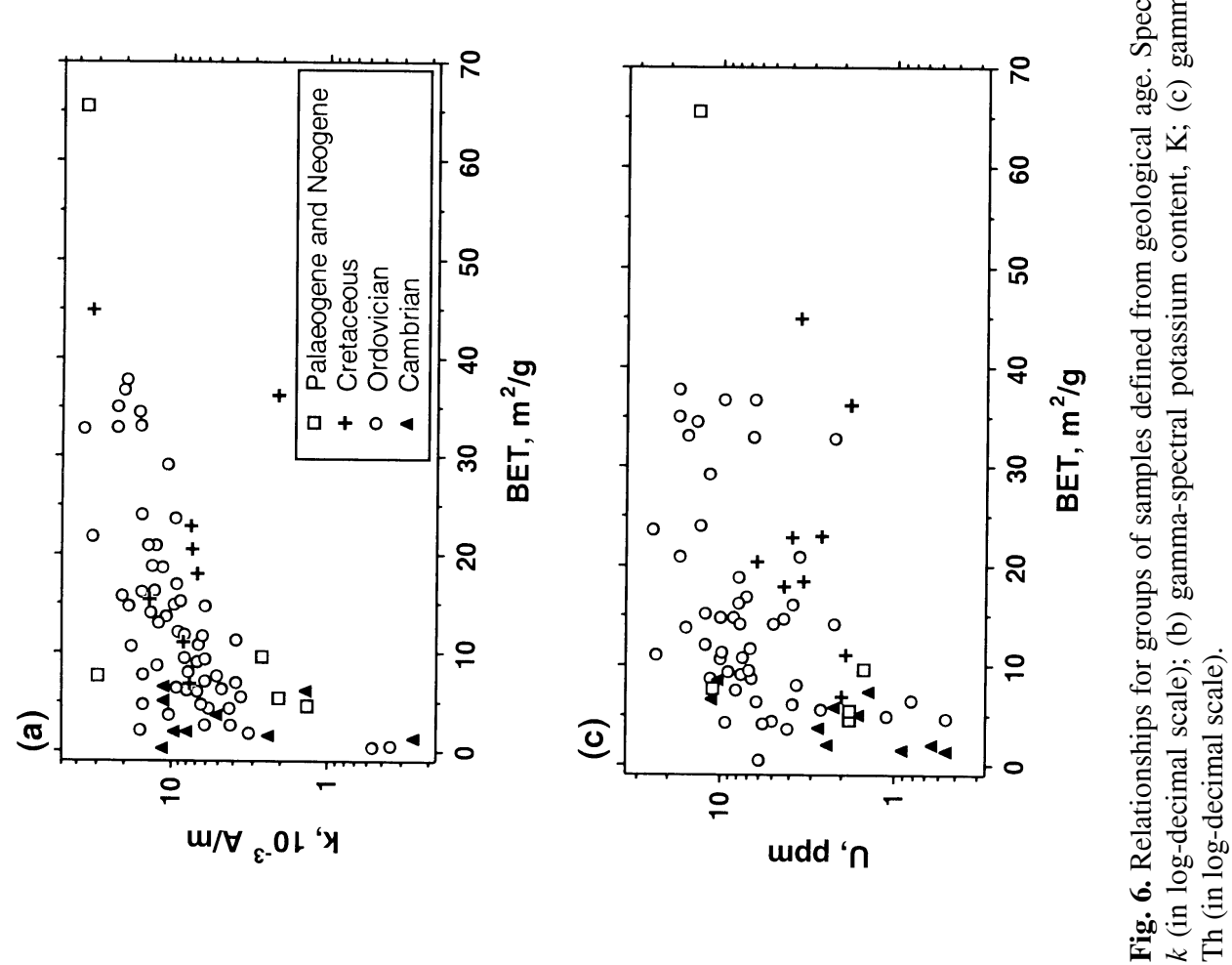

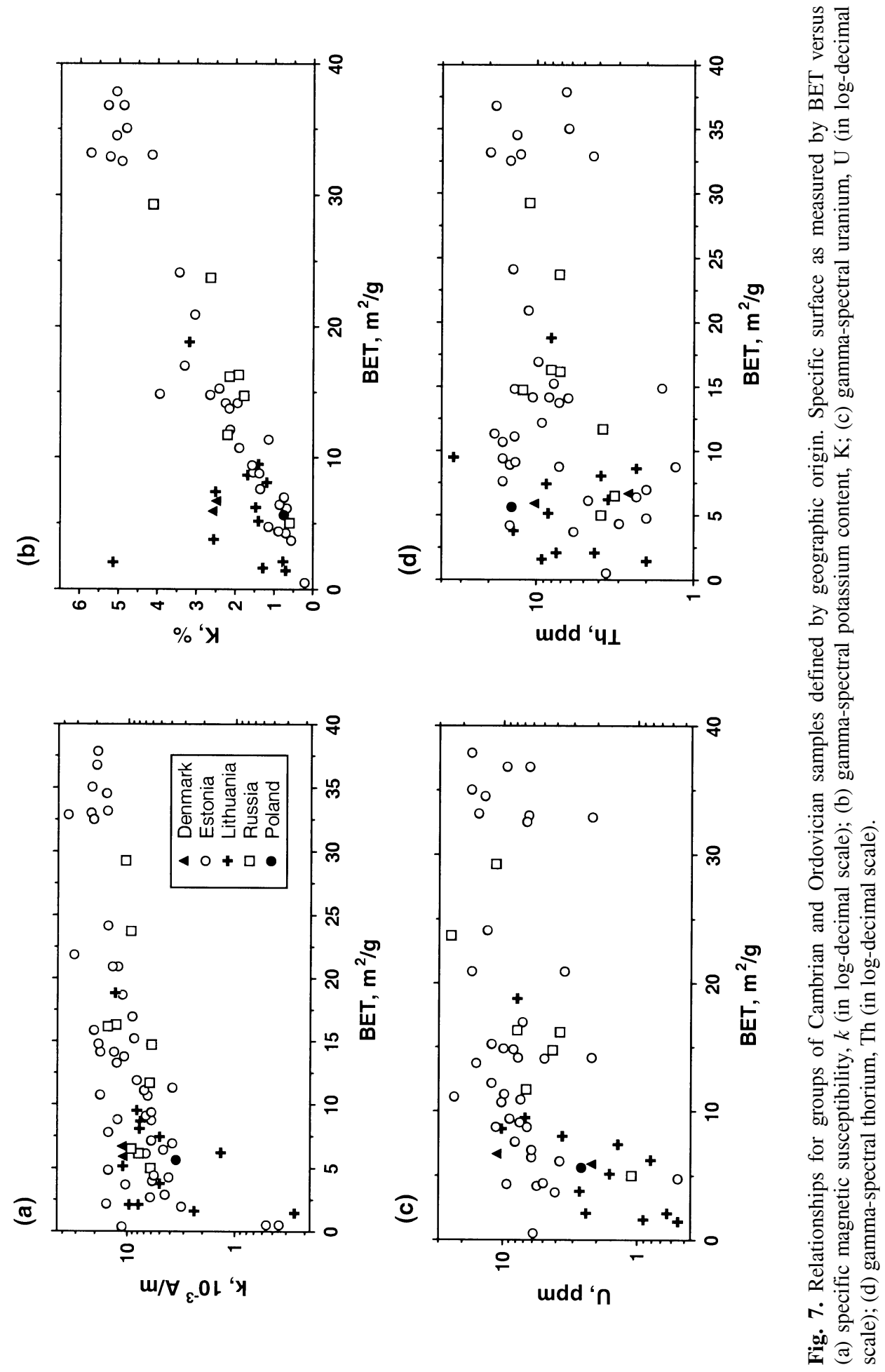


\section{RESULTS AND DISCUSSION}

For the studied samples in general, the magnetic susceptibility and potassium content were related to specific surface, whereas uranium and thorium contents gave no indication of it (Figs. 5-7). Magnetic susceptibility is related to specific surface with an overall correlation coefficient, $R=0.72$. Limestones and calcareous marlstones tend to have lower magnetic susceptibility for a given specific surface than dolomites and dolomitic marlstones. For limestones and calcareous marlstones, taken together, the correlation coefficient was 0.83 and for siliciclastics it was 0.75 . For dolomites and dolomitic marlstones the correlation coefficient was 0.69 (Fig. 5a). We found some dependence on geologic age: older rocks tend to have higher magnetic susceptibility for a given specific surface than younger rocks. Cambrian samples tend to have higher magnetic susceptibility than Ordovician samples, and these, in turn, have higher magnetic susceptibility than Cretaceous and younger samples (Fig. 6a). A possible influence of heating should reveal itself when comparing the Cambrian and Ordovician samples from different countries: Estonian and Russian samples have suffered only little, the Lithuanian samples more, and the Danish and Polish samples the most heating. There was no indication of the influence of different thermal histories on the relationship between magnetic susceptibility and specific surface (Fig. 7a).

The potassium content gave the best overall measure of specific surface, with a correlation coefficient $R=0.88$. Dolomites and siliciclastics fell along the same trend, whereas marlstones were the most scattered. A tendency that limestones have a lower $\mathrm{K}$ content for a given specific surface than dolomites and siliciclastics can also be seen (Fig. 5b). Distinct linear potassium-specific surface trends could be seen for samples of different age: older samples tended to have higher $\mathrm{K}$ for a given specific surface than younger samples (Fig. 6b). This parallels the trend found for magnetic susceptibility and may reflect an increase with age in maturity of the glauconite. The maturity also depends on thermal history: Estonian and Russian Palaeozoic samples tend to have a lower potassium content than Danish and Lithuanian samples (Fig. 7b).

Uranium has an overall positive relationship to specific surface, but no distinct trend could be defined and no clear relationship to lithology, geological age, or thermal history observed (Figs. 5c, 6c, 7c). No relationship was determined between the thorium content and specific surface (Figs. 5d, 6d, 7d).

\section{CONCLUSIONS}

The specific surface of glauconite-bearing reservoir rocks allows us to estimate the excess conductivity caused by glauconite. The specific surface can be estimated indirectly from magnetic susceptibility and potassium content as measured by gamma-spectrometry. 
The highest linear correlation with specific surface is obtained for potassium $(R=0.88)$. For samples of specified age (Cambrian or Ordovician) or thermal history the correlation is still better. The relationship is independent of lithology (limestone, dolomite, marlstones or siliciclastics).

Magnetic susceptibility has a lower correlation with specific surface $(R=0.72)$. Distinct trends are found for siliciclastics $(0.75)$, for limestones together with calcareous marlstones (0.83), and for dolomites with dolomitic marlstones (0.69). Older samples tend to have a higher magnetic susceptibility than younger, whereas thermal history has no influence on this relationship.

Uranium and thorium cannot be used for the estimation of specific surface because no well-defined correlation was seen between these elements and specific surface.

\section{ACKNOWLEDGEMENTS}

The present work was financially supported by the Nordic Energy Research Programme and Estonian Science Foundation (grant No. 4157) and project No. $0332088 \mathrm{~s} 02$ from the Ministry of Education of Estonia.

\section{REFERENCES}

Brunauer, A., Emmet, P. H. \& Teller, E. 1938. Adsorption of gases in multimolecular layers. J. Am. Chem. Soc., 60, 309-319.

Buchardt, B. \& Lewan, M. D. 1990. Reflectance of vitrinite-like macerals as a thermal maturity index in the Cambrian-Ordovician Alum Shale, southern Scandinavia: AAPG Bulletin, 74, 394-406.

Buchardt, B., Nielsen, A. T. \& Schovsbo, N. H. 1997. Alun Skiferen i Skandinavien. Geol. Tidsskr., $3,1-30$.

Cyziene, J. \& Šliaupa, S. 1999. Glauconite from lower Cretaceous and Cenomanian siliciclastic sequence of South-Eastern Lithuania: Palaeoenvironmental significance. In 4th Baltic Stratigraphic Conference. Methods of Modern Regional Stratigraphy, Abstracts, Jurmala, pp. 17-18.

DeVoe, J. R. \& Spijkerman, J. J. 1966. Mössbauer spectrometry. Anal. Chem., 38, 382-393.

Gry, H. 1960. Geology of Bornholm. International Geological Congress 21 (Norden), Excursion Guide A45 \& C40, pp. 3-16.

Hamada, G. M., Al-Blehed, M. S. \& Al-Awad, M. N. J. 1999. Nuclear magnetic resonance log evaluation of low-resistivity sandstone reservoirs. J. Eng. Appl. Sci., 46, 951-970.

Hansen, K. 1936. Die Gesteine des Unterkambriums von Bornholm. Geol. Surv. Denmark II, Vol. 62.

Meidla, T. 1997. Hunneberg Stage, Billingen Stage. In Geology and Mineral Resources of Estonia (Raukas, A. \& Teedumäe, A., eds.), pp. 58-61. Estonian Academy Publishers, Tallinn.

Modlinski, Z. \& Szymanski, B. 1997. The Ordovician lithostratigraphy of the Peribaltic Depression (NE Poland). Geol. Quarterly, 41, 273-288.

Nybakk, E. 2002. Sorption of Benzoic Acid on Glauconite. M.Sc. thesis, DTU, Denmark.

Nybakk, E., Vestergaard, L. \& Fabricius, I. L. Excess conductivity of glauconite. Petrophysics (in press).

Popov, L. (ed.). 1997. Wogogob (Working Group on Ordovician Geology of Baltoscandia). Excursion guide. St. Petersburg, Russia; Uppsala University. 


\title{
Balti piirkonna glaukoniitkivimite eripinna hindamine
}

\author{
Alla Šogenova, Ida L. Fabricius, Uffe Korsbech, Vita Rasteniene \\ ja Saulius Šliaupa \\ On uuritud Balti piirkonna 97 kivimiproovi, mis erinesid litoloogilise koostise \\ (lubjakivi, dolomiit, domeriit, mergel, purdkivimid), geoloogilise vanuse \\ (Kambrium, Ordoviitsium, Kriit, Paleogeen ja Neogeen) ja soojusastme poolest \\ (nõrgalt soojendatud kivimid Eestis ja Venemaal, enam soojendatud Leedus \\ ning enim soojendatud Taanis ja Poolas). Leiti, et glaukoniiti sisaldavate \\ hoidlakivimite eripinda saab kaudselt hinnata kaaliumisisalduse (määratud \\ gammakiirguse spektromeetria meetodiga) ja magnetilise vastuvõtlikkuse abil. \\ Kaaliumisisaldus on parem eripinna näitaja (korrelatsioonikordaja $R=0,88$ ). \\ Magnetilise vastuvõtlikkuse ja eripinna korrelatsioon on veidi väiksem $(R=0,72)$. \\ Gammakiirguse spektromeetria abil mõõdetud tooriumi- ja uraanisisaldus ei sobi \\ eripinna hindamiseks, kuna selget korrelatsiooni pole märgata.
}

